\title{
TRANSZNACIONÁLIS VÁLLALATOK HATÁRON TÚLI AKVIZÍCIÓINAK ÉS FÚZIÓINAK KÖRNYEZETI HATÁSAI
}

\author{
(Environmental Effects of Cross Border Merges \\ and Acquisitions of Transnational Companies)
}

\section{BALOGH CSABA}

Kulcsszavak:

transznacionális vállalat akvizíció fúzió környezet

A 20. század végére a világméretüvé vált globalizáció eredményeképpen létrejött transznacionális vállalatok határon túli akvizíciók és fúziók segítségével gazdasági és politikai hatalmukat igyekeznek a földkerekség egészére kiterjeszteni. A termékeik és szolgáltatásaik révén uniformizált fogyasztói társadalomnak azonban nem csak jóléti hatásai vannak. A környezetszennyezés és a katasztrófák napjaink égetõ problémái, amelyek megoldása nemcsak a transznacionális vállalatok feladata, hanem a miénk, fogyasztóké is.

\section{A multinacionális és transznacionális vállalatok kialakulása}

Egy vállalat életciklusa a teljes vállalati szintre átértelmezve lényegében hasonlóan definiálható, mint a termék életgörbe (bevezetés, növekedés, érettség és hanyatlás szakaszokra bontható) (Chikán 1994, 155). Kisebb volumenü gazdaságokkal rendelkező országok esetében hamarabb, míg nagyobb volumenü gazdaságokkal rendelkező országok esetében később a hazai vállalatok életciklusukban elérkeznek ahhoz a ponthoz, amikor a vállalati méretgazdaságosság szempontjának érvényesítése során kénytelenek átlépni a nemzeti határokat. A nemzeti vállalatokból átlépve az ország határait így lesz multinacionális vállalat (Multi National Company MNC), majd a további fejlödés során pedig transznacionális vállalat (Trans National Company - TNC).

A nemzeti határokon való átlépésnek több lehetősége van. A legismertebbeket, az 1. ábra szemlélteti.

A stratégiai szövetségeket, fúziókat, akvizíciókat és a zöldmezỏs beruházásokat a szakirodalom a közvetlen külföldi tökebefektetések (Foreign Direct Investment FDI) kategóriába sorolja. A döntés (választás az egyes eszközök közül) az egyes lehetöségek között általában a tranzakciós költségek és a vállalt kockázat alapján történik. A döntéshozók célja itt a tranzakciós költségek minimalizálása és a felvállalt kockázathoz tartozó várható hozam maximalizálása. 
Balogh Csaba : Transznacionális vállalatok határon túli akvizícióinak és fúzióinak környezeti hatásai.

Tér és Társadalom 18. évf. 2004/2. 95-106. p.

96 Gyors ténykép

TÉT XVIII. évf. 2004 a 2

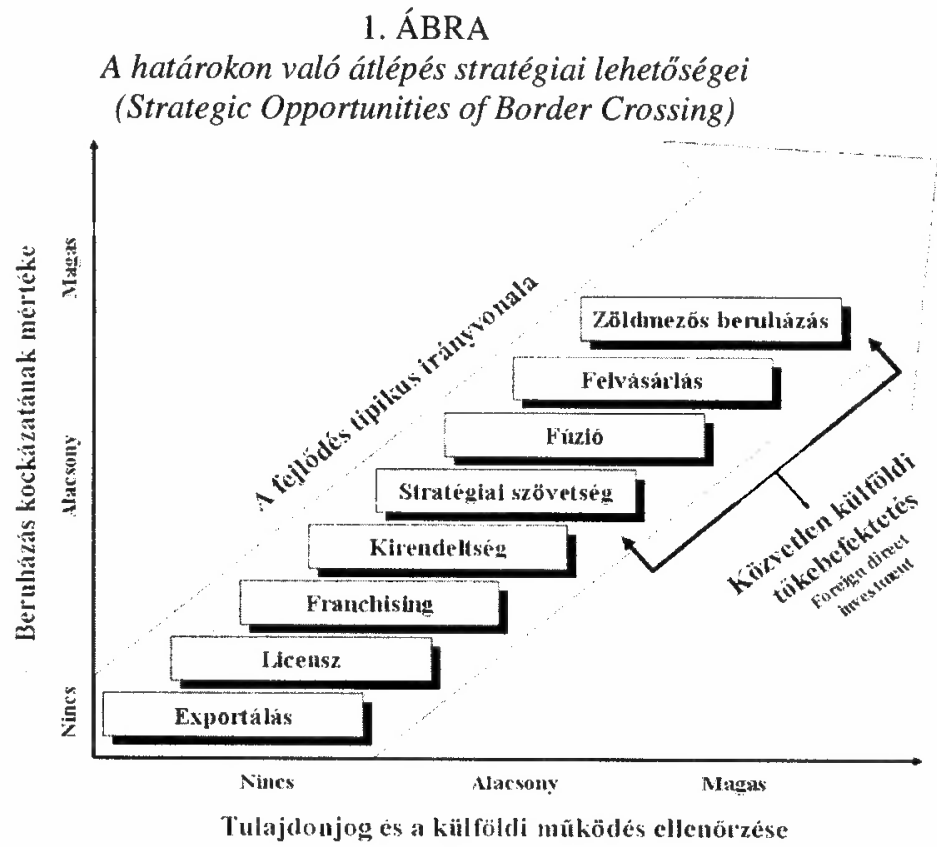

Forrás: Webster (2000)

A második világháborút követỏen a vállalatok multinacionálódási, transznacionálódási folyamata egyre nagyobb méreteket öltött. Átalakulások, cégegyesülések során egyre nagyobb és nagyobb és komplexebb vállalati struktúrák alakultak ki az erőforrás-kitermelés, a termelés, az elosztás és a marketing területén. Egyre több cég terjesztette ki tevékenységét más országokra. A cégek növekedésével egyre több multinacionális vállalat jött létre, majd a hatalom és a töke további koncentráciojával, a világkereskedelem erösödésével létrejöttek a globális, nemzetek feletti vállalatok is (GAIA 1997a, 3861). Ez a folyamat különösen megerősödött az 1990-es években. A felvázolt folyamatot a 2. ábra szemlélteti empirikus adatokkal.

A következő tényezők tették lehetövé a nagyvállalatok ilyen mértékủ terjeszkedését (Fidrich 2002a, 5):

- az egész világpiachoz való hozzáférés, a szocialista gazdaságok összeomlása,

- a harmadik világ és a volt szocialista országok piacainak megnyitása a Világbank és a Valutaalap által rájuk kényszerített szerkezetátalakítási programokon keresztül,

- a felhalmozott hatalmas államadósságok visszafizetésének érdekében exportorientált gazdaságra való átállás, s ehhez külföldi müködő tőke bevonásának igénye,

- a szabad kereskedelem útjában álló korlátok (vámok, kereskedelmi kvóták stb.) eltörlése az OECD, GATT és WTO egyezmények keretében,

- az állami tulajdonban lévő vállalatok (áramellátás, posta, bank, biztosítás, távközlés) privatizálása, 
Balogh Csaba : Transznacionális vállalatok határon túli akvizícióinak és fúzióinak környezeti hatásai.

Tér és Társadalom 18. évf. 2004/2. 95-106. p.

TÉT XVIII. évf. 2004 - 2

Gyors ténykép

97

- a szakszervezetek visszaszorítása,

- a tỏkepiacok globalizációja és az informatika fejlődése, amely gombnyomásra lehetôvé teszi dollármilliók mozgatását.

2. ÁBRA

Akvizíciós és fúziós hullámok

(Merge and Acquisition Waves)

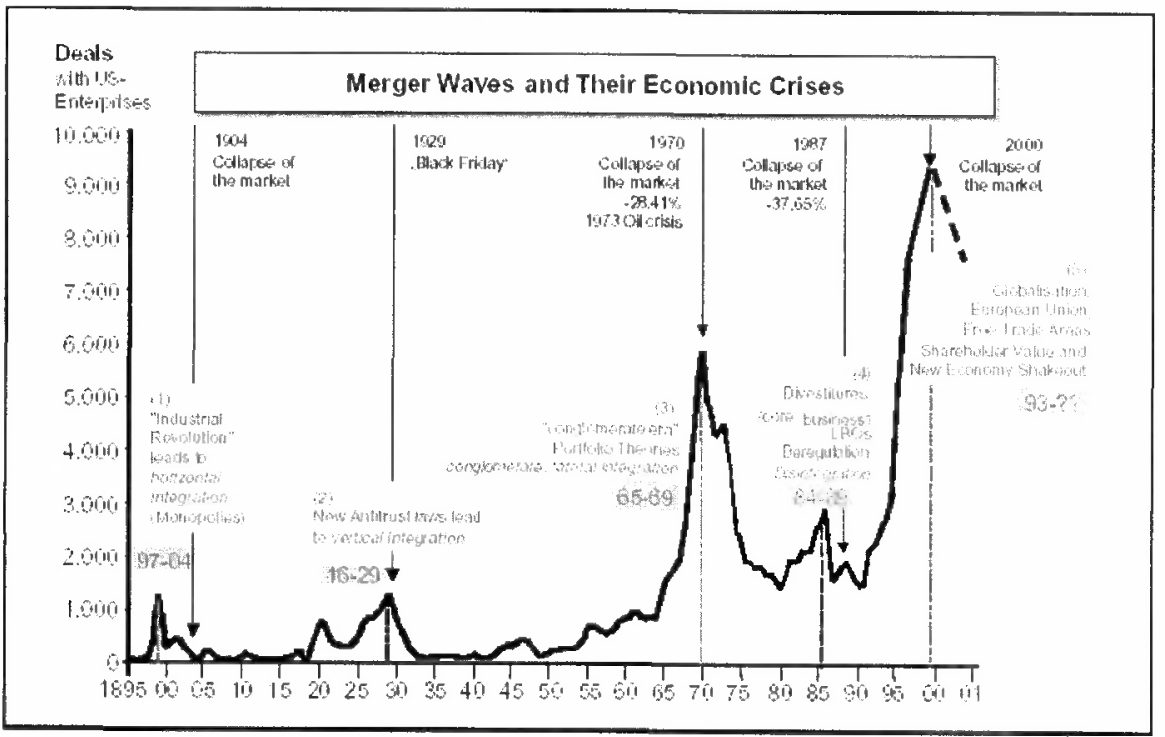

Forrás: Jansen-Müller-Stewens (2000, 2)

A világméretủ versengés felerősödése erőteljes költségcsökkentési megoldásokra kényszeríti a vállalatokat, melynek legkézenfekvóbb módja a bérkiadások lefaragása, amit a kormányzatok adópolitikája idéz elö. A bérek esetében ugyanis magasabbak a vállalkozások terhei, mint a természeti erőforrások esetében.

A nagyvállalatok jelenlegi fö irányvonala egyre többet és többet termelni egyre kevesebb munkaerővel. Az elmúlt évtizedben az 500 legnagyobb vállalatnál évente 400 ezer állás szúnt meg. A globalizáció előidézte felgyorsult gazdasági tempó következménye, hogy a vállalati növekedés leghatékonyabb eszköze nem az új beruházások létesítése, hanem a piaci részesedés bővítése a kisebb vetélytársak felvásárlásával és a vállalatok összeolvadásával.

Ezt a folyamatot látszik alátámasztani adatokkal a 3. abra, amely a határon túli akvizíciók és fúziók részarányának alakulását szemlélteti a kỏzvetlen külföldi tỏkebefektetéseken belül az idő függvényében. 
Balogh Csaba : Transznacionális vállalatok határon túli akvizícióinak és fúzióinak környezeti hatásai.

Tér és Társadalom 18. évf. 2004/2. 95-106. p.

\section{3. ÁBRA}

A közvetlen külföldi tökebefektetések (FDI) és a határon túli akvizíciók és fúziók (CBM\&A) értékeinek alakulása világviszonylatban 1987-2000 között (Mrd USD)

(The Development of the Values of Foreign Direct Investments [FDI] and Cross

Border Merges and Acquisition [CBM\&A] in the World between 1987 and 2000

[in Billion USD])

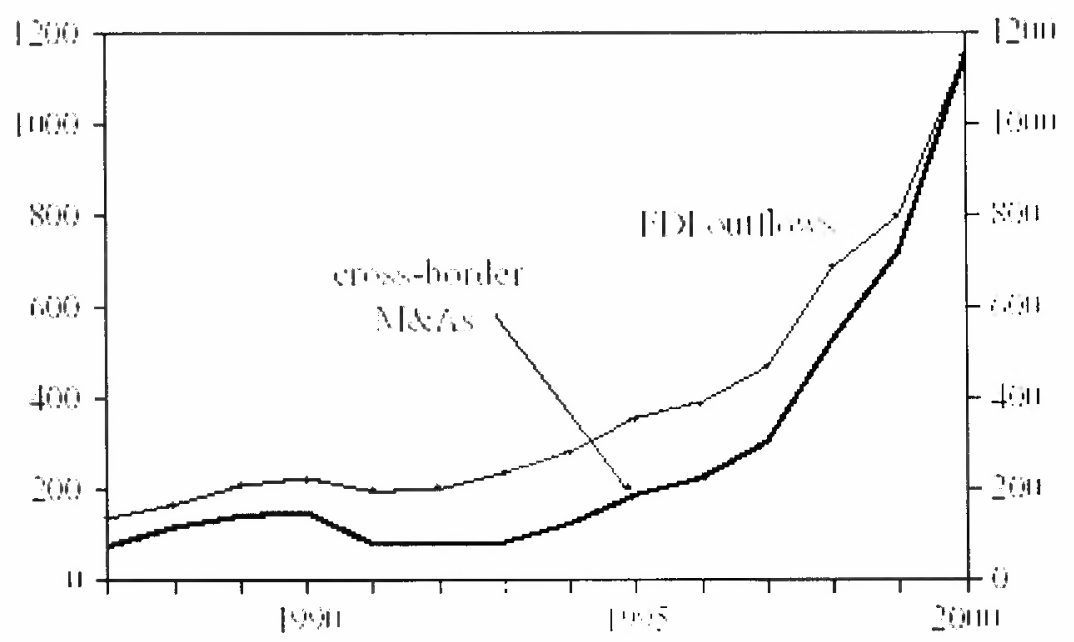

Forrás: Kleinert-Klodt (2002)

A határon túli akvizíciók és fúziók (CBM\&A) jelentőségének növekedése világviszonylatban jól látható az ábrán. Míg az 1990-es évek közepéig a CBM\&A csak $50 \%$-át tette ki az összes külföldi tőkebefektetésnek (FDI), addigra ez az arány 1999-re 84\%-ra nött, és 2000-re gyakorlatilag elérte a 100\%-ot. (CBM\&A összértéke 1144 milliárd USD, FDI összértéke 1150 milliárd USD.)

\section{A transznacionális vállalatok és a környezet}

$\mathrm{Az}$ ezredfordulóra a transznacionális vállalatok a külföldi müködőtőkeberuházások, az előzőekben ismertetett CBM\&A és vállalat összevonások következtében jelentös hatalomra tettek szert. Ez a hatalom egyre nagyobb mértékben, egyre kevesebb cég kezében összpontosul, ami lehetővé teszi számukra, hogy gazdasági hatalmuk mellett érdekvédelmi szervezeteiken, fizetett lobbistáikon keresztül országok kormányainak, sőt nagy nemzetközi intézmények (Világbank, Nemzetközi Valutaalap, Kereskedelmi Világszervezet, Európai Unió) politikájának alakulását, valamint a nemzetközi egyezmények sorsának alakulását is befolyásolni tudják (pl. kiotói, hágai klímatárgyalások) (GAlA 1998, 4103).

A transznacionális vállalatok ezen hatalma mellett eltörpül a felelösségvállalásuk mértéke. Legtöbb esetben igyekeznek kibújni mindenféle jogi felelősség alól, tevékenységüket nagyon gyakran kíséri környezetszennyezés. 
Balogh Csaba : Transznacionális vállalatok határon túli akvizícióinak és fúzióinak környezeti hatásai. Tér és Társadalom 18. évf. 2004/2. 95-106. p.

A transznacionális vállalatok a globalizáció nyújtotta lehetőségeket kihasználva CBM\&A segítségével gyakran helyezik ki termelésüket olyan országokba, ahol alacsonyabb szintü környezetvédelmi szabályozások vannak. A környezeti tényezők kihasználása által motivált nemzetközi tökemozgásokat nevezi a szakirodalom környezeti célú tökemenekülésnek. Rövid távon a környezeti célú tökemenekülés leginkább a már említett közvetlen külföldi tőkebefektetések (FDI) formájában realizálódik. Az ilyen típusú tökemozgást azok a vállalkozások termelésí költségeiben jelentkezö különbségek váltják ki, amelyek a környezeti szabályozás szigorában jelentkezö, országok közötti eltérésekböl fakadnak (Kaderják 1996, 1077). Egy ország javuló környezetminőségéböl származó jóléti nyereségek mellett számolni kell azokkal a jóléti veszteségekkel, amelyek a szabályozás által leginkább sújtotta iparágak leépüléséből, az érintett vállalatok telephelyeinek lazább környezeti szabályozást érvényesítő országba telepítéséből, azaz munkahelyek elvesztéséből fakadnak. Másik oldalról a környezeti követelmények érvényesítése terén kisebb szigort felmutató országok inkább attól tarthatnak, hogy miközben az olcsó környezeti szolgáltatások kiaknázása céljából beáramló küllföldi tőke szerepvállalása rỏvid távon érzékelhetô előnyökkel jár számukra, a szennyezés-intenzív tevékenységekre való specializálódás végül zsákutcás gazdasági stratégiának bizonyulhat (Kaderják 1996, 1077). Erre a lehetőségre ökológiai gyarmatosításként hivatkoznak a környezetvédök.

A közvetlen külföldi befektetések fó donorországai a ma létezö legszigorúbb környezeti szabályozással jellemezhetô országok közé tartoznak. Ezzel szemben a fogadó országokra a laza környezeti szabályozás, s ennek következtében a környezeti szolgáltatások, szennyezés relatíve alacsony ára a jellemző.

A természeti eröforrások kiaknázása az egyik terület, ahol a jelenlegi gazdasági rendszer logikája nem illeszkedik a valósághoz, és ezzel jelentős környezeti és társadalmi károkat okoz világszerte. Mára ez a szektor nagymértékben liberalizált, föleg a világ szegényebb részein. Ennek a folyamatnak a célja az elözőekben említett - külföldi befektetöknek az adott országba való „csalogatása” -, minél kedvezőbb és olcsóbb hozzáférést biztosítva az erőforrásokhoz azt hangoztatva, hogy a befektetésektöl gazdagabb lesz az ország, és a jólét növekedni fog. Ez azonban nem biztos, hogy igaz. A CBM\&A hatásait az ázsiai újjáépítésre vizsgálva Mody és Negishi arra a megállapításra jutott, hogy rövid távon az említett tranzakciók nem járulnak hozzá a gazdasági fellendüléshez (Mody-Negishi 2000). A természeti erőforrások kiaknázásával valami véglegesen eltủnhet az ország tulajdonából, és melléktermékként gyakran környezeti rombolás és jelentős társadalmi problémák keletkezhetnek.

A környezeti felelősséggel kapcsolatos jogszabályok szigorítása következtében az utóbbi évtizedben egyre több ország kerül dilemmába környezetvédelmi jogszabályainak szigorítása során, ugyanis, ha szigorúbb jellegü intézkedéseket kívánnak hozni, a transznacionális vállalatok gyakran zsarolják a kormányokat azzal, hogy amennyiben a termelési feltételek számukra kedvezőtlenül alakulnak, kiviszik gyáraikat az országból. 
Balogh Csaba : Transznacionális vállalatok határon túli akvizícióinak és fúzióinak környezeti hatásai. Tér és Társadalom 18. évf. 2004/2. 95-106. p.

2001 februárjában a Nestlé büki állateledelt gyártó üzemének használatbavételi engedélyét a Vas Megyei Közigazgatási Hivatal visszavonta, mert az nem rendelkezett a megfelelö környezetvédelmi engedélyekkel. A Nestlé svájci központja azzal fenyegetözött, hogy kivonulnak Magyarországról (Fidrich 2002a, 18).

Ezzel egybehangzóan a magyarországi privatizációval kapcsolatosan már a privatizáció kezdetén sokan ökogyarmatosításról beszéltek, amit Kerekes szerint egyébként tényekkel nem sikerült senkinek alátámasztani (Kerekes 2003).

Mint azt az elözőekben olvashattuk, a környezet károsításában a transznacionális vállalatok koránt sem tekinthetők ,ártatlan bárányoknak”. Ha nevesíteni szeretnénk az általuk okozott legjelentősebb környezeti károkat, akkor a teljesség igénye nélkül a következö föbb megállapításokat tehetjük (GAIA 1997b, 3861-3862; www.kornyezetvedelemlap.hu):

- ök bocsátják ki az ipari eredetü üvegházgázok több mint felét (BPAmoco, ExxonMobil, Shell, Chevron Texaco);

- teljesen az ő kezükben van az ózonkárosító freonok előállítása és hasznosítása (ICI, DuPont);

- a bányászatban is a nemzetek feletti cégek a fő kulcsszereplők (6 vállalat ellenörzi a világ alumínium-kitermelésének $63 \%$-át). A bányászati tevékenységek rengeteg problémával járnak: helyi lakosok kitelepítése, élöhelyek elpusztítása, folyószennyezés (Rio Tinto Zink, Newmont, Esmeralda);

- a mezőgazdaságban ők ellenörzik a kivitelre szánt termények termőterületének $80 \%$-át; 20 vállalat ellenörzi a növényvédőszer-eladások $90 \%$-át;

- ők felelősek elsősorban a környezetkárosító technológiák és termékek átadásáért: pl. az 1980-as évek végén az USA növényvédöszer-kivitelének 25\%-át otthon már betiltott termékek alkották;

- reklámjaikkal pazarlo és fenntarthatatlan életmódra serkentenek.

A következőkben nézzünk meg néhány példát a legismertebb transznacionális vállalatok által okozott környezeti katasztrófákat illetően, amelyek során a természetben óriási károk keletkeztek. Az egyes esetek leírása a napi sajtó hírei, illetve a környezetvédők honlapjain található információk alapján került összeállításra.

A századvég egyik legnagyobb környezetvédelmi katasztrófája az Union Carbide bhopali vegyipari gyárában történt 1984 decemberében, amikor a gyárból kiszabadult a mérgező metilizocianát. Az elsó héten hatezer ember halt meg. Azóta 16 ezerre emelkedett a halálos áldozatok száma, és több százezerre tehetö azok száma, akik valamiféle egészségkárosodást szenvedtek. A mérgezettek között följegyeztek vese, lép és májkárosodást. Csökkent a mérgezettek immunitása, könnyebben betegszenek meg például tbc-ben. Mutációk jelentkeztek a mérgezettek gyermekeinél. A környezetvédők szerint a biztonsági rendszer nem volt megfelelö, $\mathrm{s}$ ezt tudták a gyár vezetői is (GAIA 1994, 3332).

Az ExxonMobil vállalat a két olajipari óriás, az Exxon és a Mobil egyesülésével jött létre 1999-ben. Föleg az Exxonnak van rossz híre a zöld szervezetek között, de 
Balogh Csaba : Transznacionális vállalatok határon túli akvizícióinak és fúzióinak környezeti hatásai.

Tér és Társadalom 18. évf. 2004/2. 95-106. p.

szerintük az is köztudomású, hogy a kiotói éghajlatváltozási keretegyezmény legföbb ellenzője az Exxon és a Mobil volt.

1989. március 24-én Alaszka partjainál zátonyra futott az Exxon Valdez tankhajó, s a kiömlött 11 millió hordó nyersolaj ökológiai katasztrófát okozott. Az olajszenynyezéstöl tömegével elhullott állatok képe bejárta a világsajtót. Becslések szerint mintegy 100-300 ezer madár válhatott a katasztrófa áldozatává. Több mint ezer fokozottan védett rozmár is elpusztult a baleset következtében. A partvidék több mint $1400 \mathrm{~km}$ hosszan szennyezödött (Exxon Valdez ... 1989).

1998-ban az Egyesült Államok igazságügy-minisztériuma a Tiszta Levegö törvény 200 alkalommal történỏ megsértésével vádolta meg az Exxont. A Citizens for a Better Environment szervezet több tízezer ivóvízforrás elszennyezése miatt okolta az Exxont.

1998 januárjában több mint 40 ezer hordó olaj ömlött ki a Mobil olajvezetékéből Nigéria partjainál (Move Military... 1999).

$\mathrm{Az}$ ExxonMobil vezette konzorcium kezdte el építeni a Csád-Kamerun Köolajvezetéket. A beruházás jelentős tiltakozást váltott ki a társadalmi szervezetek körében. A tervek szerint egy $650 \mathrm{~km}$ hosszú köolajvezeték épül Csádból a Guineaiöbölig. Kameruni parti esőerdökön, fontos folyórendszereken vezetne keresztül. A környezetvédő szervezetek az erdőirtás, folyószennyezés miatt aggódnak. A Világbank is elismeri, hogy a beruházás a térségben az olajipari fejlesztések erősödéséhez, valamint az üvegház gázok hosszú távú felhalmozódásához vezet, az egész bolygó környezeti állapotát veszélyeztetve.

A DuPont vezető szerepet játszott az ózonréteg pusztításában, az Egyesült Államok egyik legnagyobb veszélyeshulladék-termelöje és az ólomtartalmú benzinadalékok egyik utolsó elöállítója volt. A DuPont találta ki a freonokat, és állította elö ezek világtermelésének $25 \%$-át. A cég növényvédö szereket is gyárt, és Floridában eddig már több mint 500 millió dollár kártérítést kellett fizetnie a Benlate nevủ szer által a talajban és a termésben okozott károk miatt. A DuPont 1991-ben 120 ezer tonna veszélyes hulladékot termelt az USA-ban - az EPA szerint többet, mint bármely más vállalat. 1991 márciusában a DuPont Quimica Flour nevủ mexikói gyára körül annyira elszennyeződött a környezet, hogy a kormány 30 ezer család kitelepítését rendelte el (EPA 1999).

A Mitsubishi vállalatcsoportot komoly felelősség terheli a világ esőerdeinek eltünése kapcsán. Mára a társaság a világ legnagyobb fakitermelöjévé nőtte ki magát. Kivágják a fákat a Fülöp-szigeteken, Malaysiában, Indonéziában, Pápua Új Guineában és valószínủ az érdekeltségük a burmai, thaiföldi, vietnami, kambodzsai, laoszi fakitermelésekben. Tevékenyek Dél-Amerikában, Brazíliában, Bolíviában és Chilében, valamint Szibériában. Kanadában mindenütt jelen vannak. Ott a sarkvidéki öserdőket irtják. A környezetvédők szerint a Mitsubishi cég vádolható törvénytelen fakitermelés, a szennyezési határértékek megsértése, adócsalás stb. miatt (International... 1996). A társaság radioaktív anyagokkal szennyezte Malajziát (ritkaföldfémek termelése során keletkezett hulladék helytelen tárolása révén), 14 atomerömüvet épített Japánban és továbbiakat Kínában és Indonéziában. 
Balogh Csaba : Transznacionális vállalatok határon túli akvizícióinak és fúzióinak környezeti hatásai. Tér és Társadalom 18. évf. 2004/2. 95-106. p.

A térségünket is érintö romániai Nagybányán tevékenykedö Aurul bányavállalat ügye valószínüleg mindenki elött ismert. 2000. január 30-án több mint 100 ezer köbméter cianid-tartalmú szennyvíz ömlött a Zazar folyón keresztül a Szamosba, majd a Tiszába, és végül elszennyezte a Dunát is. A szennyezés következtében óriási mértékben károsodott a Szamos és a Tisza élövilága, több mint ezer tonna hal pusztult el, köztük védett fajok is. A meddöböl ciános technológiával aranyat kitermelö ausztrál-román Aurul vegyesvállalat olyan körülmények között végezte a tevékenységét, amelynek szinte törvényszerü következménye volt a baleset. Az ausztrál tulajdonos Esmeralda Ltd. valószínüleg a gyenge környezetvédelmi szabályozások miatt építette fel a vállalatát Nagybányán. A minél nagyobb mértékü haszonszerzést előtérbe helyezték a környezetvédelmi érdekekhez képest. A magyar állam 29,3 milliárd Ft-os kárigényt nyújtott be a céggel szemben. Az ügyben az Aurul SA ill, az ausztrál tulajdonos Esmeralda Ltd. mellett a Dresdner Bank is érintett, ugyanis 8,5 millió dollár kölcsönnel támogatták a beruházást. A per során a cég megpróbálja húzni az időt. Az első tárgyaláson az Aurul helyett a korábban ismeretlen, Transgold nevü cég jogi képviselöje jelent meg, arra kényszerítve a bíróságot, hogy a jogállás tisztázásáig elnapolja az ügyet (Ciándosszié 2000).

A környezeti felelösséggel kapcsolatos jogszabályok szigorítása következtében az utóbbi évtizedben egyre több ország jogi szabályozása teszi a szennyezett terület tulajdonosa számára kötelezővé a szennyezés felszámolását. Ez természetesen igen komoly befolyást gyakorolt az ingatlanpiacra, és a vásárlások elötti környezeti átvilágítás végzésére késztette a vásárlót.

A környezeti terhek vizsgálatára akkor kerül sor, ha egy adott terület tulajdonost cserél, vagy jelzálog kerül rá, s a potenciális új tulajdonos tudni szeretné, hogy az adott területhez nem kapcsolódik-e olyan mértékü környezetszennyezésből adódó költség, amely jelentősen befolyásolja az adott ingatlan vagy vállalat értékét. A környezeti átvilágítás ezen formáját gyakran nevezik ,szennyezés felmérés”-nek.

A környezetszennyezés bizonyos típusaira az a jellemző, hogy hosszú ideig képesek rejtve maradni, sőt halmozódni bármilyen probléma okozása nélkül. Ez az idő akár több évtized is lehet, pl. az elásott veszélyes hulladékok esetében. A környezetszennyezés ezen formái mintegy időzített bombaként ketyegnek, hisz bármikor komoly problémák okozóivá válhatnak (pl. a hulladékokból egészségre káros anyagok mosódhatnak ki és kerülhetnek a talajvízbe, majd a kutakba). Felszámolásuk ezért előbb vagy utóbb szükségessé válik. A környezeti terhekből adódó költségeket a szakirodalom a következőképpen csoportosítja:

- a terület megtisztításának költségei,

- a jogszabályok betartásához szükséges többletköltségek,

- a potenciális környezeti kockázatok csökkentésének költségei,

- környezetvédelmi felelösségből adódó költségek (Kerekes-Kindler 1998, 16). 
Balogh Csaba : Transznacionális vállalatok határon túli akvizícióinak és fúzióinak környezeti hatásai. Tér és Társadalom 18. évf. 2004/2. 95-106. p.

Az esetleges környezetszennyezés felszámolásának költségeit érthető módon nem kívánja viselni az új tulajdonos. A környezetszennyezés értékcsökkentö hatása érvényesül még akkor is:

- ha az adott országban pillanatnyilag nincs olyan jogszabály érvényben, amely annak felszámolására kötelezné a tulajdonost,

- ha a régi tulajdonos vétlen a környezet szennyezésében (tehát nem számít, hogy esetleg egy még korábbi terület-felhasználó helyezte el az adott területen a veszélyes hulladékait a jelenlegi tulajdonos tudta nélkül),

- ha a környezet szennyezését a szennyezés idején érvényes jogszabályokat nem sértve okozták (Kerekes-Kindler 1998, 16).

\section{A környezeti kockázat megosztása az eladó és a vevö között}

Jogosan merül fel a kérdés, hogy tulajdonképpen kinek is kell fedeznie a környezeti károk költségeit. Ezen költségek nyilván csökkentik az eladásra felkínált vállalat értékét, azonban a költségek viselésének konkrét módjára vonatkozóan a vevő és az eladó többféleképpen is megállapodhat.

Ha a vevő és az eladó a szerződésben nem köt külön megállapodást a környezeti terhek viselésére vonatkozóan, akkor a vevő mint jogutód fogja a környezeti terheket viselni. A szerződésben azonban ettöl eltérő módon is megállapodhatnak.

A vevő és az eladó megállapodhat abban, hogy a szerződés megkötése után napvilágra került környezeti károkért a korábbi eladó viseli a felelősséget. Ha tehát ilyen károk felmerülnek, az új tulajdonos a korábbi eladó költségére végeztetheti el a helyreállítási munkálatokat. Ez esetben nincs szükség környezeti átvilágításra. Az eladó említett felelősségét a szerzödésben korlátozhatják idöben és értékben is, így elkerülhetôvé válhatnak bizonyos kétes esetek, mint pl. ha a környezeti károk költsége meghaladja a vételi árat, akkor az eladó korlátlan felelőssége esetén többet kellene fizetnie a vevőnek, mint a kapott teljes vételi ár. A felelősség időben való korlátozása is logikus, mivel az idő múltával egyre nehezebben állapítható meg, hogy a környezeti károk mely része tudható be a korábbi eladó, és mely része a jelenlegi tulajdonos tevékenységének (Kerekes-Kindler 1998, 28).

A környezeti károk rendezésének ezen módja azonban igen komoly kockázatot rejt magában, elsősorban az eladóra vonatkozóan. Az adás-vételnél ugyanis az új tulajdonosnak érdeke füződik a környezeti károk feltárásához és ahhoz, hogy azokat az eladó költségére felszámolja. Mivel azonban nem az új tulajdonos viseli a költségeket, nem érdekelt költséghatékony megoldás megtalálásában: valószínủbb, hogy a legbiztosabb és legdrágább megoldásokat választja még akkor is, ha ez nem indokolt. Éppen ezért a felelősség ilyen módon való rendezése nem ajánlható, bár bizonyos esetekben - pl. az eladó pillanatnyi pénzügyi nehézségei - elkerülhetetlenné teszik alkalmazását.

A környezeti károk kezelésének ezen módjára a legismertebb példa a LEHEL privatizációja. A Lehelt 5 milliárd Fteért értékesítette az ÁVÜ az Elektroluxnak. A Tulajdonrész Vételi Szerződést 1991. április elsején írta alá az ÁVÜ és az 
Balogh Csaba : Transznacionális vállalatok határon túli akvizícióinak és fúzióinak környezeti hatásai. Tér és Társadalom 18. évf. 2004/2. 95-106. p.

Elektrolux, s a szerződésben az ÁVÜ felelősséget vállalt az ismeretlen mértékủ környezeti károk felszámolására. Ez a felelösség nem volt sem idöben, sem anyagi értelemben korlátozva. Az adás-vétel megtörténte után az Elektrolux átvilágítást végeztetett a területen, és a károk helyrehozatalának költségeiért a számlát benyújtotta az ÁVÜ-nek. A vételárat majdnem teljes részben kénytelen visszafizetni az ÁVÜ a környezetszennyezés felszámolásának költségére (Pethö 1999; Jegyzökönyv 2000a).

Ha a szerzödés nem tartalmaz kikötést a környezeti károkra vonatkozóan, akkor a vevő mint jogutód örökli a kockázatokat. Ebben az esetben azonban érdekében áll az eladási árból árengedményt kérni, amely fedezi a környezeti károk rendezésével, illetve a kockázatokkal kapcsolatosan jövőben felmerülő költségeit. Az adás-vétel elött kömyezeti átvilágítással tisztázzák a károk mértékét. Ez azt a célt szolgálja, hogy még az adás-vétel előtt pontosan tisztázzák a károk és költségek mértékét, és megvédjék mind az eladót, mind pedig a vevőt attól, hogy a jövőben ismeretlen mértékủ környezeti kockázatokkal kelljen szembenézniük.

A megoldás előnyös az eladó számára, hiszen nem kell felelőséget vállalnia ismeretlen kockázatokért, és azt sem kockáztatja, hogy a jövőben az új tulajdonos eltúlzott mértékü környezetvédelmi költségek fedezésére nyújt be számlát. A finanszírozási gondokkal küszködő eladó mégis rákényszerülhet arra, hogy ne ezt a technikát válaszsza, hiszen így azonnali költségei merülnek fel mind az átvilágításból, mind pedig az árengedmény adásának kötelezettségéböl adódóan, szemben más megoldásokkal, amikor a környezeti kockázatokból fakadó költségei csak a jövőben jelentkeznek.

Néha alkalmazzák azt a megoldást is, amikor az eladó továbbra is felelősséget vállal a környezeti kockázatok azon részére, amit az átvilágítás esetleg nem tárt fel.

Magyarországon a Kiskunsági Állami Gazdaság privatizációja szolgál példával. 1982-től kezdődően a vállalat vezetői festék- és oldószermaradványokat tartalmazó hordókat vettek át és ásattak el a gazdaság területén. A veszélyes hulladék tömege 1730 tonnára rúgott, és körülbelül 9 ezer hektár területet kellett helyreállítani. A vevő, a Danube Farm Ltd. árengedményt kapott azért cserébe, hogy viselje a terület megtisztításáért a felelősséget. A szerződés aláírásának időpontjában már rendelkezésre állt egy átvilágítás jelentése a károkra vonatkozó részletes adatokkal, valamint az is ismeretes volt, hogy egy környezetvédelmi vállalkozás 120 millió Ft-ért vállalja a helyreállítási munkálatokat.

A szennyezést nem szükséges minden áron eladni a vállalattal együtt. A vállalat bizonyos esetekben részekre osztható, és egyes részek tehermentesen értékesíthetöek, miközben a kömyezeti károkkal terhelt rész nem kerül értékesítésre. Ezzel gyakorlatilag a jövőbe toljuk a problémákat. A vevő számára a megoldás nem foglal magában környezeti kockázatokat.

Jó példa erre a TVM privatizációja. A TVM-et három részre bontva sikerült privatizálni. A mosóport elóállító egységet megvette a Henkel, a festékuizemet a Holland Colonis, míg a vegyi üzem az 550 millió $\mathrm{m}^{3}$ veszélyes hulladék felszámolásának kötelezettségével együtt állami kézben maradt. Mint azt a példa is jól szemlélteti, a „Fekete Péter” ebben az esetben az állam kezében maradt. A hulladékok eltávolítására 
Balogh Csaba : Transznacionális vállalatok határon túli akvizícióinak és fúzióinak környezeti hatásai. Tér és Társadalom 18. évf. 2004/2. 95-106. p.

nincsenek meg az anyagi források, így azok egyelöre továbbra is a lerakóban maradnak (Tokár 2000).

Lehetséges megoldás, hogy az eladó mielőtt értékesítené az ingatlant, a környezeti károkat saját költségén felszámolja. Ez azonban gyakran nem célravezető megoldás. Az eladó ugyanis nem ismerheti pontosan, milyen célra kívánja az új tulajdonos a területet használni, így nagyon könnyen olyan költségekbe verheti magát, amelyet az alkufolyamatban nem tud érvényesíteni.

\section{Összefoglalás}

Mint azt olvashattuk, a transznacionális vállalatok határon túli akvizícióinak és fúzióinak nemcsak a tulajdonosok számára érzékelhető hasznai vannak, hanem igen komoly negatív következményei is lehetnek az érintettek egyes csoportjaira nézve.

Esetenként a tulajdonosi érték-növekedés forrása kifejezetten valamely más érintettnek (pl. lakosság, alkalmazottak, környezet stb.) okozott kárként ölt testet. Ezen nulla összegú játékban azonban az említett transznacionális vállalatok legtöbb esetben eröfölényben vannak, köszönhetően túlzott gazdasági és politikai hatalmuknak.

A feladat az egyes egyének számára, mint ezen transznacionális vállalatok termékeinek és szolgáltatásainak fogyasztói számára, nem más, mint (felismerve a változatlan fogyasztói magatartás jövőbeli negatív következményeit) fogyasztói szokásaik módosításával elérni, hogy ezen transznacionális vállalatok változtassanak jelenlegi hozzáállásukon (kivéve azon transznacionális vállalatokat, amelyek a tanulmányban említett problémákkal nem jellemezhetők), mert ezt a fogyasztók saját hosszú távú érdekei kívánják meg. Az egyén önmagában erre nem képes, de ha kellően sokan képesek felismerni, és hajlandóak előtérbe helyezni hosszú távú érdekeiket a rövid távú elönyökkel szemben, akkor a cél elérése nem reménytelen.

\section{Irodalom}

Chikán A. (1994) Vállalatgazdaságtan. KJK - Aula Kiadó, Budapest.

Ciándosszié (2000) Újra müködik az Aurul. 2000. június. 14. http://index.hu/politika/belfold/ciandosszie EPA (1999) EPA Complaint Against DuPont for not Alerting EPA of possible adverse effects of a pesticide. Headquarters Press Release Washington D.C. 1999.10.14.

Exxon Valdez 1989 to now. (1989) www.newsaic.com/caseindex.html

Exxon Valdez Case study, www.american.edu/TED/EXXON.htm

Fidrich R. (2002a) Globalizáció és környezet. Globalizáció füzetek. Magyar Természetvédők Szövetsége, Budapest.

Fidrich R. (2002b) Nemzetek feletti vállalatok a globalizáció korában. Miért nem szeretik a "zöldek" a nemzetek feletti vállalatokat? Globalizáció füzetek 2. Magyar Természetvédők Szövetsége, Budapest.

GAIA (1994) 10 éve Bhopal utån. - GAIA Sajtószemle. 12. évf. 272. 3332. o.

GAIA (1997a) A nemzetek feletti gulag. - GAIA Sajtószemle. 15. évf. 316. 3861. o.

GAIA (1997b) A nemzetek feletti vállalatok és a globalizáció: Az ökológiai válság súlyosbodásának alapvető okai. - GAIA Sajtószemle. 15. évf. 316. 3861-3862. o.

GAIA (1998) A kormányok nyomás alatt állnak...-GAlA Sajtószemle. 16. évf. 336. 4103.0.

International Protests Against Mitsubishi's Forest Conduct. (1996) - Worldwide Forest/Biodiversity Campaign News. 1996. 10. 22. http:forests.org/recent/1996mitspro.htm 
Balogh Csaba : Transznacionális vállalatok határon túli akvizícióinak és fúzióinak környezeti hatásai.

Tér és Társadalom 18. évf. 2004/2. 95-106. p.

106 Gyors ténykép

TÉT XVIII. évf. 2004 - 2

Jansen, S.A.-Müller-Stewens, G. (2000) Endet die fünfte Welle auf dem Markt für Unternehmensübernahmen in einer neuen Rezession? Geschichte, Trends und Erfolgsfaktoren von Zusammenschlussen. - Frankfurter Allgemeine Zeitung. 4. 10. 49. o.

Jegyzökönyv (2000a) Lehel privatizációs ügye. http://emil.alarmix.org/ecology/bizottsag/ szoszerint/jegyzokonyv2000may16IV.htm

Jegyzökönyv (2000b) TVM privatizációs ügye. http://emil.alarmix.org/ecology/bizottsag/szoszerint/ jegyzokonyv2000may 16IV.htm

Kaderják P. (1996) A hazai közvetlen kủlfoòldi befektetéseket meghatározó tényezökről - egy kvantitatív elemzés. - Közgazdasági Szemle. 12. 1072-1087. o.

Kerekes S. (2003) Környezetgazdaságtan és menedzsment II. PhD kurzus elöadás. BKÁE, Budapest.

Kerekes S.-Kindler J. (1998) Vállalati környezet-menedzsment. BKE, Budapest.

Kleinert, J.-Klodt, H. (2002) Causes and Consequences of Merger Waves. Working Paper No. 1092. Kiel Institute of World Economics, Kiel.

Mody, A.-Negishi, S. (2000) The role of CBM\&A in Asian. Restructuring World Bank.

Move Military Crackdowns for Oil in Nigeria. (1999) - Washington Peace Letter. 1.

Pethö L. (1999) Egy mikrorégió az ezredfordulón. MTA politikai Tudományok Intézete és a Jászberényi Tanítóképzõ Fóiskola Kơzmüvelődési és Felnóttnevelési Tanszéke, Budapest.

Tokár I. (2000) TVM privatizáció. Parlamenti felszólalás. http://www.mkogy.hu/naplo/052/0520025.htm Webster, G.H. (2000) Strategic alliances. Power point presentation file. 